\title{
Optimizing the Clerics (Religious Scholars) Role in Actualizing Good Governance Concept
}

\author{
Muhammadong1, St Habibah*2, Dalilul Falihin ${ }^{3}$, Muhammad Adnan Hudain ${ }^{4}$ \\ ${ }^{1,3,4}$ Sports Science Faculty, UniversitasNegeri Makassar, Makassar, Indonesia \\ *25ekolah Tinggi Agama Islam (STAI) Al-Furqan Makassar, Makassar, Indonesia \\ e-mail: shabibah34@gmail.com
}

\begin{abstract}
The purpose of this research is to describe the role of the clerics to actualize good governance concept in the development of Makassar City. Therefore, clerics are not merely issuing "fatwas" (religious advises) for the sake of society, but also, clerics can also play a role in development process. The method applied in this research is a descriptive method. While the approach applied is a qualitative method because the issues that are studied are phenomenological. The results show that the role of clerics is optimal in actualizing good governance concept in Makassar City development process. The role and function of the clerics can be represented as a community counselor in line with the government's role as servant and protector of society. Moreover, the policy taken by the government has been supported by all the clerics in actualizing development programs for the mutual good of the societies. In making strategic decisions, clerics sometimes contribute and suggestions to the government to improve social support of that decision.
\end{abstract}

Keywords-Role, clerics; good governance.

\section{INTRODUCTION}

Islam is a universal treatise, which governs all human beings [1]. Islam also regulates the whole matter of life as well as the whole relationship between life with something else that exists before and the afterlife. Islam also solves all human problems as creatures, (who have physical needs, instincts, and mind). It also regulates the human interaction and interaction with God and at any time and place.

A verse expression in Al Qur'an in Surah Fathir verse 28 this verse explicitly reveals that the clerics are not an ordinary people, but also religious servants who always obey the command of their God [2]. However, in this terminology, it does not mean that the clerics or religious scholars must obey everything. Instead, clerics should also be able to demonstrate the ability to practice religious principles to compete with modernization.

However, the conventional perception of the clerics sometimes experiences narrowing, as if the clerics only pursue the science of religion while neglecting another field of development. As the implication of narrowing the definition of understanding the concept of clerics, the attitude emerges is to prioritize the science of religion, but underestimate other science which is not applicable to the social concept. 
Clerics or religious scholars in the context of Islamic teachings is not only those who are experts in the science of religion but all those who know, both religious knowledge and general science [3]. With their knowledge, they can function primarily as a successor to the message from the Prophets Muhammad SAW as the Messenger of Allah SWT. The clerics or scholars can be regarded as scientists as well. It is just that clerics or scholars possess the characteristic of uswatunhasanah who should be an example.

The cleric's role as the leading actors impacts the history of human life [4]. In various figures, clerics as "scenario" of life that has been given by Allah SWT. The clerics might be present as a "faqih" who can formulate and map issues in society. The clerics might present as a " $d a^{\prime} i$ " who convey the issues that have been formulated and mapped. The clerics might have a role as a "technocratic" figure who is capable of mastering technological issues. Ultimately, the clerics might have a fighter role who can defend the rights of the people.

In line with the role of clerics, the task of government has also governed the society [5]. Therefore, the government can understand the aspirations of the society. The government has a role as a liaison catalyst for every interest group in the community and as a driver of all forms of community activities. The government should be sensitive to the changes that occur in society, not to be unaware of the demand that occurred which can cause government failure because of its resistance to social change. The government is also in charge of designing the various policies.

About Islam as the religion, the right governance concept is part of the siyasah (governance) issue because all policies are taken by the government based on the results of human thought to realize the welfare of the people and avoid the damage of the community. Also, the implementation of policies taken by the government is in line with Islamic teachings so that the ideals of good governance can be achieved. A good governance relationship lies in the regulation, control, and implementation system within a country or region. In siyasah, policy or decision is often based on Islamic teachings or divine revelations (top-down), while good governance concept departs from human thinking (bottom up).

This study aimed to describe the role of clerics in realizing good governance concept in Makassar City. Therefore, clerics are not just issuing fatwas in religious studies, but they can be significant other of government. Governance cannot work well if the clerics are not involved although the involvement of clerics is indirectly at least they can give input to the government.

\section{METHOD}

This study was conducted at the Indonesian Ulama Council (MUI) of Makassar City. From its type, this study is categorized as an explorative study. The object studied is the nature and symptoms of an individual as the qualitative method can point human as an instrument[6]. The data collected in this study is phenomenological, namely the role of clerics in actualizing good governance concept in Makassar City development programs. The 
instrument used in this study is an interview protocol to provide data collections and simplify collecting data process. The interview conducted not to get out of the focus of research and prepared based on research indicators. It is intended to be a guideline in conducting interviews and can be done by going directly to the research location by making observations with the informants that have been set.

Data analysis technique used in this qualitative study is data reduction, data presentation, and data verification about clerics' role in realizing good governance in Makassar City. Analyzing qualitative data can be performed with organizing data and sorting data into manageable units, synthesizing, searching and finding patterns, find what is essential and what is learned, and deciding what can be told to others [7].

\section{RESULTS}

The results showed that the clerics or religious scholars have a significant role in realizing the government development programs in Makassar City. The function and role of clerics as a community counselor is in line with the government's role in developing and managing of society. Therefore, sometimes the government of Makassar City needs support from the clerics in actualizing development programs. Due to achieve the form of good governance as a concept of development.

It seems that the clerics in Makassar were very responsive and sensitive role to the behavior and lifestyle of the society. For example; Indonesian Ulama Council (MUI) of Makassar City issued a fatwa about haram or prohibition in littering and suggest society be wiser. This fatwa has issued an implementation of the Qur'an teachings, and the hadith of Prophet Muhammad SAW who teaches cleanliness as part of the Islamic religion. The clerics argued that the clean culture carried out by the citizens would have a positive impact in their life. However, the dirty culture was carried out and bring mudharat effect both to themselves and to the environment. The clerics considered that by keeping the environment clean, the government program could be performed very well.

In line with this fatwa, the establishment of a fatwa from MUI Makassar City to address the lifestyle of the community not to dispose of garbage in any place. In line with the slogan of a government program that is "Makassar ta' TidakRantasa"" (Not Dirty Makassar). The issue of the fatwa of Indonesian Ulama Council that ban on littering in the environment as one of the government programs that Makassar City could become a world city that provides a comfortable situation for its citizens through environment care. In contrast, the impact of disposing of garbage in any place, not merely cause environmental damage, but far beyond the life of residents increasingly disturbed. Although the fatwa issued by the Indonesian Ulama Council (MUI) of Makassar City, it is not directly related to the government's program on "Makassar ta' TidakRantasa." Implicitly, it seems that the 
synergy exists between clerics or religious scholars and Government in realizing universal goodness. Eventually, the community makes Makassar as a clean city so that its citizens can live comfortably and free from disease.

Fatwas issued by MUI Makassar is an implementation of good governance. One of the principles that have been implemented is a commitment to environmental protection. This principle was developed by the MUI to make Makassar clean and environmentally friendly city. This fatwa is issued as a response of Ulama to the complaint of the people. Hence they can avoid the disease. The principle of the rule of government in good governance has been applied in the fatwa of MajelisUlama Indonesia. Consequently, people can maintain diversity in Makassar City to establish interreligious harmony. Through this fatwa, the people of Makassar City can help the government in actualizing the government through the unity regardless religious differences.

The clerics in Makassar City appreciate highly the value of diversity that becomes the central pillar of the state. The clerics are expected to give a calm and peaceful atmosphere for the people primarily related to their/or community religion so that there is no conflict of SARA (ethnic, religion, race). One of the critical fatwa on religious harmony issued by MajelisUlama Indonesia as said by the Chairman of the MUI of Makassar, KH. Baharuddin AS, namely: 1) Christmas celebration in Indonesia, although the purpose of celebrating and honoring the Prophet Isa, but Christmas cannot be separated from the issue of harmony; 2) Joining a Christmas ceremony for Muslims is forbidden; and 3) In order for Muslims not to fall into syubhat and prohibition of Allah SWT, it is recommended not to follow the activities of Christmas.

To reinforce the government commitment, the government of Makassar City has cooperation with da'wah institutions held a da'i event which is held annually involving the clerics and the da'i in Makassar City. This activity is held to have common perception and established communication between government and religious scholars. The purpose of the event is giving the community awareness of Makassar City on the meaning of harmony among religious people to establish brotherhood among citizens to maintain the diversity of the society in Makassar City.

Interfaith harmony fatwa is one of the important issues in religion. Hence the citizens of Makassar can be united in the system of government and cannot be provoked easily. Moreover, people who live in the city of Makassar realize the diversity and are familiar with the cross-cultural understanding. Religious harmony fatwa is not just to unite citizens, but the government can efficiently run the government with the awareness of its citizens in addressing the differences.

To improve the community awareness of the dangers of HIV/AIDS, the clerics in Makassar City always provide counseling to the citizens. The counseling was in the form of direct guidance and dialogue or training approach to make them aware of the repercussion. Clerics performed their function well as an extension of Islam by continuing to preach the teachings and invite to the excellent community livelihood. The role of the clerics is a manifestation of the government program. It can be said that clerics are the 
most active element in direct contact with the community. The government realized that cooperation between the people and the government did not go without the support of the clerics.

The fatwas issued by clerics in Makassar are the answer to the casuistic problems occurred in society to actualize the development of the Makassar City. The synergy between the government and the clerics is evidence of the achievement of good governance concept can be implemented in Makassar City. The clerics always respond to every event that occurred in the city of Makassar, not because they are asked to do the development role but not more than the humanitarian role. Thus, the people of Makassar City feel the comfort and peace in their livelihood because the clerics always finds a solution to the confronted issues. Moreover, in the society, good governance can only be achieved if there is cooperation between the three elements, namely government, clerics, and society. This aspect is established to make Makassar City can be a pilot of other areas in South Sulawesi in particular and Indonesia in general.

\section{IV.DISCUSSION}

Islam has brought the rules of plenary, capable of solving all the problems of interaction within the state and society. The rules govern in the fields of governance, economics, social, education and political issues, both national and international concerning the general interaction between state and community members, or among countries and between people and nations, and between war and peace. Alternatively, concerning the specific interaction between members of one community and other members of society, the universality of Islam listed in Al-Qur'an Surah Al-Anbiya verse 21.

The role of clerics as the Prophet Muhammad SAW followers at least can be spelled out in the four main tasks that must be executed in developing and implementing the holy book of the Qur'an in the society. Firstly, convey the teachings by the command of Allah SWT. Secondly, explain the teachings based on the verses of Qur'an. Thirdly, decides cases or issues faced by society. Fourthly, gives exemplary to the community about the behavior of the Prophet Muhammad SAW. These four tasks are the clerics' role in modeling goodness in society and guiding overcome the destruction of the social issues. Therefore, clerics will lead to "musabaqah bi alkhaerat" and become a problem solver in social problem of the society [2].

Even though, specifically, the clerics have a role to perform "Amar makruf" and "Nahimungkar" as the guidance of Rasulullah Muhammad SAW. They must actively establish the monotheism and science achievements in the direction of Allah SWT in the Qur'an Surah al-Jumuah verse 2 . He who has sent among the unlettered a Messenger from themselves reciting to them His verses and purifying them and teaching them the Book of command and wisdom - although they were before in clear error.

IJoASER, Volume 1, Issue 1, March 2018

DOI: 10.33648 /ijoaser.v1i1.3

Copyright: STAI Al-Furqan Makassar,Indonesia

Content License: CC-BY-SA 
Nowadays, clerics are expected to play a role in the process of changing the world towards modernization also a model of development.

Moreover, clerics should not alienate themselves from the changing of the society during the times. They are needed to solve the issues that exist in the society. They should establish good cooperation with the government as the main player of development. Therefore, amar ma'ruf and nahi mungkar as the concept of Islamic role in the community can be actualized. Clerics and government are partners who can actualize good governance.

The clerics and government in Makassar City have a mutual need to maintain diversity livelihoods. The government of Makassar City needs clerics to get formal legal support not only in religious matters, but clerics are also needed in government issues so that people can peacefully support the development. The government cannot actualize development when the clerics do not take an active role. Thus, the synergy of both is needed to actualize good governance in Makassar.

Rasulullah SAW has implemented the issue of good governance statement in "siyasah" form [8]. It can be seen after the Messenger of Allah emigrated from Mecca to Medina to organize and direct his people towards the socio-cultural stratum. His position as head of government, all the policies of the Messenger of Allah is the implementation of siyasah. The manifestation of siyasah can be seen in the Prophet's policy of communicating the intern of the Muslims, as between the Muhajirin and the Ansar groups. The integration of Islamic teachings with good governance is part of the strategy of the Prophet to organize the life of the people of Madinah to actualize diversity.

The study of good governance is part of muamalah and the arguments relating to it in large part in the form of general principles identified with Zanni (unattached). Good governance is a study with Zanni characteristic whose existence can be developed by humans about the needs and human benefits that cannot be separated from the demands of place and time. Development of functional governance concept regarding muamalah requires the involvement of human thought because it is something defined as ma'qul al-ma'na (reachable by human reason) about the benefits it contains. With the involvement and attachment of human thought to change of place and time, the field of muamalah is the field of ijtihad. The object of ijtihad is anything that is not regulated explicitly in legal issues that the main rules are not found. Thus, good governance in Islamic study is ijtihad movement.

The role of clerics in Makassar is not a determinant of policy but more dominant to provide oversight to the government. Furthermore, supervision of MajelisUlama Indonesia is non-structural that can provide input to the government so that the government can run well. Fatwas issued by clerics in Makassar City apparently can contribute significantly to the government. Not that the clerics' fatwa is present in Makassar to respond to the government's political wishes, but as a counterweight to the policies adopted by the government.

The role of clerics in Makassar City is needed to create a balance between physical and mental development. Therefore people can find the direction of his life. One of the factors of moral decadence in Makassar City involving 
teenagers, because mental development gets attention less. Therefore they are very easy to commit a crime, for example, a robbery by a motorcycle gang. Also, formal education which is conducted in school or college does not become a benchmark in making changes. Thus the role of clerics is the main pillar in making improvements and changes regarding development in Makassar City.

The role of clerics in Makassar City in actualizing good governance should be given a bigger portion to make governance run well. Clerics should not just give a fatwa to make people aware of the Islamic religion. However, more than that, clerics or scholars should play an active role in various fields, both social and governmental. In carrying out their duties, clerics should not be independent but requires the hint of society and government support. Thus the role of clerics as a guardian, protector, and guidance in society can be actualized through collective work.

That humans have an obligation to maintaining the nature and environment to maintain its existence on earth. Nature must be treated humanly [9]. Therefore, people can live peacefully because humans are given some potential by Allah All Mighty God to manage the nature. The task of a cleric is to direct human beings to be mental and moral guidance to preserve they are morally based on religious teachings. The goal to be achieved in preserving nature and the environment is to run amar ma'ruf nahi munkar so that humans avoid danger. The impact that occurs when the clean environment will affect the spirit because there is a reciprocal relationship in turn. Similarly vice-versa, for instance, the dirty environment will affect a person's psychic so he cannot pray well.

The indicators of good governance in the clerics view for actualizing development can be oriented on: 1) creating a conducive atmosphere for the community to fulfill their spiritual needs. The enforcement of the prayer can symbolize it; 2) the creation of prosperity and economic welfare can be symbolized by the act of paying zakat (donation); 3) the creation of political stability and security can be accompanied by the action of amar ma'ruf nahi munkar [10]. Thus, good governance can formulate based on three aspects, which are: 1) spiritual governance; 2) economic governance; and 3) political governance.

MUI fatwas issued by the clerics in response to Makassar City answering the issues confronted in the community. The act of establishing fatwa becomes an independent profession. However, in many Muslim countries, the fatwas become associated with state authority in various ways. While in Indonesia, the fatwa is an Islamic legal thought and plays a vital role in addressing the problems of the society.

For some scholars, the fatwa is a transformation of Islamic law to answer the question of casuistry to fill the legal void when Muslims need certainty about a problem [11]. Although it is not attractive and compelling, the fatwa can be a sedative for a group of people. The release of clerics' fatwa on 
religious tolerance in Makassar City is the answer to the pluralistic problem to avoid a conflict between religious people who lead to division.

\section{CONCLUSION}

In the era of globalization, the role of clerics is needed in society. Without the clerics, the government cannot perform their duties and functions to provide services to the community. Clerics do not merely give fatwa to society. However, clerics can be other half of the government. Therefore the formulations issued by the clerics can be input and consideration of government to run their role.

Clerics today find difficulties to develop their knowledge and their preach if the communities become an obstacle. Thus, between clerics and society should work together to build better next generations. Therefore, clerics and society become the determining factor also in actualizing development of the city of Makassar. Eventually, good governance can only be realized in Makassar City if the three pillars are united consists of government, clerics, and society.

\section{REFERENCES}

[1] T. An-Nabhani, "SistemPemerintahan Islam: Doktrin, SejarahdanRealitasEmpirik," Bangil: Al'Izzah, 1996.

[2] M. Q. Shihab, "Wawasan al-Qur'an," Bandung: Mizan, vol. 1419, 2016.

[3] B. I. Asghary, "SOLUSI ALQURAN: Tentang Problem SosialPolitikBudaya," Jakarta: RinekaCipta, 2014.

[4] M. Ruslan, "Ulama Sulawesi Slatan: BiografiPendidikandanDakwah," KomisiInformasidanKomunikasi MUI Sulsel: Makassar. 2007.

[5] B. Istianto, Manajemenpemerintahandalamperspektifpelayananpublik. Kerjasama STIAMI Jakarta denganMitraWacana Media, 2009.

[6] L. J. Moleong, "Metodologipenelitian," Bandung PT. RemajaRosdaKarya, 1999.

[7] M. Nazir, "MetodePenelitian Cet. 9," PenerbitGhaliaIndones. Bogor, 2014.

[8] A. Djazuli, "FiqhSiyasah: ImplementasiKemaslahatanUmmatdalamRambuRambuSyari'ah, edisiRevisi," Jakarta Jakarta Putra Graf., 2007.

[9] H. Nasution, "Islam RasionalGagasandanPemikiran," 1995.

[10] M. Iqbal and M. Ag, FiqhSiyasahKonstekstualisasiDoktrinPolitik Islam. Kencana, 2016.

[11] H. Z. Ali, Hukum Islam: PengantarIlmuHukum Islam di Indonesia. SinarGrafika, 2008. 